\title{
Pseudotumor cerebri in childhood and adolescence: data from a specialized service
}

\author{
Pseudotumor cerebral na infância e adolescência: dados de um serviço especializado \\ Gabriela G. M. Balbi', Sandro L. Matas², Claudio A. Len', Melissa M. Fraga', Iggor O. Sousaํ', Maria Teresa Terreri'
}

\begin{abstract}
Objective: To report cases of children and adolescents diagnosed with pseudotumor cerebri associated or not with rheumatic disease. Methods: This was a retrospective study based on medical reports of 29 patients, up to 18 years of age and diagnosed with pseudotumor cerebri, followed up in the Pediatric Rheumatology and Neurology outpatient clinics of a tertiary hospital, until December 2016. Results: Among the 29 patients diagnosed with pseudotumor cerebri, $51.7 \%$ were girls and the mean age at the disease onset was 12.3 years. In 18 patients (62\%) where an etiology was found, four were associated with a rheumatic disease. The most common symptom was headache (69\%) and acetazolamide was the most used medication (69\%). Two patients developed blindness and 10 are still being followed up. Conclusion: Although rare, pseudotumor cerebri should be considered in children with headaches, especially in patients with rheumatic disease.
\end{abstract}

Keywords: Pseudotumor cerebri; headache; rheumatic diseases; childhood.

\section{RESUMO}

Relatar os casos de crianças e adolescentes com diagnóstico de pseudotumor cerebral com ou sem doença reumática. Métodos: Estudo retrospectivo através de revisão de prontuários, 29 pacientes com idade até 18 anos e diagnóstico de pseudotumor, atendidos nos ambulatórios de Reumatologia Pediátrica e Neurologia de um hospital terciário, registrados até dezembro de 2016. Resultados: Dentre os 29 pacientes com diagnóstico de pseudotumor cerebral, 51,7\% eram meninas. A média de idade de aparecimento dos sintomas foi de 12,3 anos. Em relação à etiologia do pseudotumor cerebral, em 18 pacientes (62\%) foi possível identificar uma causa, sendo o diagnóstico de doença reumática associada em quatro desses casos. Cefaléia foi o sintoma mais frequente (69\%), e a medicação mais utilizada foi a acetazolamida (69\%). Dois pacientes evoluíram para cegueira e 10 ainda se encontram em seguimento ambulatorial. Conclusão: Concluímos que, apesar de raro, o diagnóstico de pseudotumor cerebral deve ser considerado em crianças com cefaleia, principalmente nos pacientes com doença reumática.

Palavras-chave: Pseudotumor cerebral; cefaleia; doenças reumáticas; infância.

Pseudotumor cerebri, or benign intracranial hypertension, is a syndrome that presents with clinical features of elevated intracranial pressure without radiological evidence of an intracranial mass, infection, vascular abnormality, hydrocephalus or changes in the level of consciousness ${ }^{1,2,3,4,5}$.

The incidence of pseudotumor cerebri in general population is $1: 100,000$. It is rare in childhood. The incidence increases between the ages of 12 and 15 years, and $60 \%$ of the children who develop the syndrome are over 10 years of age $e^{2,6,7,8}$.

The pathogenesis of pseudotumor cerebri is still unknown; some hypotheses include decreased absorption of cerebrospinal fluid (CSF) associated with vascular resistance in the sinus $\mathrm{s}^{2,7,10,10,11}$.

Several conditions are associated with pseudotumor cerebri (secondary pseudotumor), such as systemic diseases and drug exposure. The term idiopathic intracranial hypertension is used when the cause of this condition is not found ${ }^{12,13,14}$.

There are few studies in the literature, most of which are case reports, describing secondary pseudotumor syndrome in Pediatrics. Our objective was to report all cases of children and adolescents diagnosed with pseudotumor cerebri, with or without rheumatic disease, who were followed by the pediatric rheumatologists and neurologists of our hospital.

¿Universidade Federal de São Paulo, Departamento de Pediatria, Unidade de Reumatologia Pediátrica, São Paulo SP, Brasil;

¿Universidade Federal de São Paulo, Departamento de Líquido Cefalorraquidiano, São Paulo SP, Brasil.

Correspondence: Gabriela G. M. Balbi; Unidade de Reumatologia Pediátrica da UNIFESP; Rua Borges Lagoa, 802; $04021-001$ São Paulo SP, Brasil; E-mail: gabrielagmbalbi@gmail.com

Conflict of interest: There is no conflict of interest to declare.

Received 24 February 2018; Received in final form 27 May 2018; Accepted 15 August 2018. 


\section{METHODS}

This was a retrospective cohort study evaluating 29 patients, up to 18 years of age, with the diagnosis of pseudotumor cerebri according to the criteria of Dandy et al. ${ }^{15,16}$ modified by Rangwala and $\mathrm{Liu}^{17}$. Patients were selected from the Pediatric Rheumatology and Neurology outpatient clinics of the Federal University of São Paulo, in Brazil, until December 2016. The following data were analyzed: demographics, pseudotumor etiology, clinical features, treatment and outcome. All patients underwent diagnostic spinal manometry with opening pressure equivalent to or greater than $25 \mathrm{~mm}$ of water ${ }^{17}$.

\section{RESULTS}

Of the 29 patients, $51.7 \%$ (15 patients) were girls. The mean age of symptom onset was $12.3 \pm 4.3$ years. The mean age at first evaluation was $15.4 \pm 4.4$ years.

Regarding the etiology of the pseudotumor cerebri, $11(37.9 \%)$ patients were diagnosed with idiopathic pseudotumor and 18 patients (62.1\%) had secondary pseudotumors. In four of these latter patients (13.8\%) a rheumatic disease was identified. Among these, two had juvenile dermatomyositis undergoing oral glucocorticoid withdrawal. One patient had Henoch-Schönlein purpura, and was also receiving glucocorticoids. The fourth patient presented with antiphospholipid antibody syndrome. Other causes were obesity/overweight (three patients), use of drugs such as tacrolimus and growth hormone (two), renal transplantation (two), cavernous sinus thrombosis (two), hypervitaminosis A (one), Bardet-Biedl syndrome (one), cranial trauma (one), immune thrombocytopenic purpura (one), and cavernous angioma (one). Table 1 shows the demographic characteristics and etiology of the pseudotumor cerebri patients.

The most frequent symptoms and signs were: papilledema and headaches in 20 patients (69.0\%), decreased visual acuity in 16 (55.2\%), and nausea and vomiting in seven (24.1\%).

Headache occurred in 13 patients with secondary pseudotumor and in seven patients with primary pseudotumor. The most frequent characteristics of the headaches were: holocranial location with nuchal irradiation, continuous, worse at night and in the mornings and in some cases associated with nausea and vomiting.

Table 2 shows the signs and symptoms presented by each patient.

Imaging studies were performed on all patients. The findings included: empty sella, prominent gyri and sulci, and optic nerve sheath edema.

The most commonly-used medication was acetazolamide as monotherapy in $20(69.0 \%)$ patients and in combination with topiramate in four $(13.8 \%)$ patients. Nine (31.0\%)
Table 1. Demographic characteristics and etiology of cerebral pseudotumor in 29 patients.

\begin{tabular}{|c|c|c|c|}
\hline Patient & Sex & $\begin{array}{l}\text { Age diagnosis } \\
\text { (years) }\end{array}$ & Etiology \\
\hline 1 & Male & 14 & Renal transplantation \\
\hline 2 & Male & 9 & Idiopathic \\
\hline 3 & Male & 18 & Hypervitaminosis A \\
\hline 4 & Female & 14 & Cavernous sinus thrombosis \\
\hline 5 & Male & 6 & Idiopathic \\
\hline 6 & Male & 17 & Renal transplantation \\
\hline 7 & Female & 12 & Cavernous angioma \\
\hline 8 & Male & 6 & Cranial trauma \\
\hline 9 & Female & 18 & Idiopathic \\
\hline 10 & Male & 10 & Idiopathic \\
\hline 11 & Male & 10 & Idiopathic \\
\hline 12 & Female & 12 & Obesity \\
\hline 13 & Female & 16 & Overweight \\
\hline 14 & Female & 10 & Growth hormone use \\
\hline 15 & Female & 17 & Idiopathic \\
\hline 16 & Male & 11 & Idiopathic \\
\hline 17 & Female & 19 & Bardet-Biedl syndrome \\
\hline 18 & Female & 8 & Idiopathic \\
\hline 19 & Female & 18 & Idiopathic \\
\hline 20 & Female & 9 & Antiphospholipid syndrome \\
\hline 21 & Female & 5 & Juvenile dermatomyositis \\
\hline 22 & Female & 18 & Idiopathic \\
\hline 23 & Male & 15 & Idiopathic \\
\hline 24 & Female & 13 & Tacrolimus use \\
\hline 25 & Female & 14 & Obesity \\
\hline 26 & Male & 6 & Henoch-Schönlein Purpura \\
\hline 27 & Male & 7 & $\begin{array}{l}\text { Immune thrombocytopenic } \\
\text { purpura }\end{array}$ \\
\hline 28 & Male & 15 & Cavernous sinus thrombosis \\
\hline 29 & Male & 12 & Juvenile dermatomyositis \\
\hline
\end{tabular}

patients did not use any drug treatment. Table 3 shows the treatment for each patient.

Regarding the outcome, there was a resolution of the condition in 27 patients. Two patients developed blindness (partial/total) due to pseudotumor cerebri and there were no deaths. The median of time until clinical resolution was 120 days (ranging from 14 to 1,800 days) and 10 patients are still being followed up as outpatients.

\section{DISCUSSION}

Pseudotumor cerebri is a rare condition in childhood and adolescence. Association with other entities and prognosis differ from the adult presentation due to lower rates of chronicity and recurrence ${ }^{8,18}$. In our study, we observed a 
Table 2. Signs and symptoms presented by 29 patients with cerebral pseudotumor.

\begin{tabular}{|c|c|c|c|c|}
\hline Patient & Headache & Nausea/vomiting & $\begin{array}{c}\text { Visual } \\
\text { loss }\end{array}$ & Papilledema \\
\hline 1 & No & No & No & No \\
\hline 2 & Yes & No & Yes & Yes \\
\hline 3 & Yes & No & Yes & Yes \\
\hline 4 & No & No & No & No \\
\hline 5 & No & No & No & No \\
\hline 6 & Yes & No & Yes & Yes \\
\hline 7 & Yes & Yes & Yes & Yes \\
\hline 8 & Yes & No & Yes & No \\
\hline 9 & Yes & v & Yes & Yes \\
\hline 10 & Yes & Yes & Yes & Yes \\
\hline 11 & No & Yes & No & Yes \\
\hline 12 & Yes & Yes & No & Yes \\
\hline 13 & Yes & No & Yes & Yes \\
\hline 14 & Yes & No & No & Yes \\
\hline 15 & Yes & No & Yes & No \\
\hline 16 & No & No & No & Yes \\
\hline 17 & Yes & No & Yes & No \\
\hline 18 & No & No & No & Yes \\
\hline 19 & Yes & Yes & No & Yes \\
\hline 20 & Yes & No & Yes & Yes \\
\hline 21 & Yes & No & No & Yes \\
\hline 22 & Yes & No & No & No \\
\hline 23 & No & No & Yes & Yes \\
\hline 24 & Yes & No & Yes & Yes \\
\hline 25 & Yes & No & Yes & Yes \\
\hline 26 & No & No & No & No \\
\hline 27 & No & No & Yes & Yes \\
\hline 28 & Yes & Yes & No & No \\
\hline 29 & Yes & Yes & Yes & Yes \\
\hline
\end{tabular}

predominance of secondary disease with an association with rheumatic diseases in about a quarter of the identifiable etiologies. We found a positive outcome in most cases, with the exception of visual sequelae in two patients.

The mean age of onset of the pseudotumor cerebri was approximately 12 years and the youngest patient was five years old. This finding is consistent with Babikian et al., who reported that approximately $60 \%$ of pediatric patients with pseudotumor cerebri were 10 years of age or older ${ }^{19}$. Disease frequency increases with age and peaks in adolescence $^{3}$. In our study, sex did not influence the frequency of the disease ${ }^{8,20}$.

Clinical criteria are well established. We used Dandy's ${ }^{15}$ criteria, modified by Friedman and adapted for children by Rangwala and $\mathrm{Liu}^{16}$. The definition of normal spinal manometry is still controversial. Several authors postulate that opening pressure is related to the age group and to the presence
Table 3. Treatment of 29 patients with cerebral pseudotumor.

\begin{tabular}{|c|c|c|c|}
\hline Patient & Medication & $\begin{array}{l}\text { Lumbar } \\
\text { puncture }\end{array}$ & $\begin{array}{l}\text { Spinal } \\
\text { shunt }\end{array}$ \\
\hline 1 & No & No & No \\
\hline 2 & Acetazolamide & No & No \\
\hline 3 & Acetazolamide & Yes & No \\
\hline 4 & No & No & No \\
\hline 5 & No & No & No \\
\hline 6 & Acetazolamide & Yes & No \\
\hline 7 & Acetazolamide & Yes & No \\
\hline 8 & Acetazolamide & Yes & Yes \\
\hline 9 & No & No & No \\
\hline 10 & Acetazolamide + Slow-K & No & No \\
\hline 11 & Acetazolamide & No & No \\
\hline 12 & $\begin{array}{c}\text { Acetazolamide }+ \\
\text { Topiramate }\end{array}$ & No & Yes \\
\hline 13 & No & Yes & Yes \\
\hline 14 & $\begin{array}{c}\text { Acetazolamide }+ \\
\text { Topiramate }\end{array}$ & Yes & Yes \\
\hline 15 & Acetazolamide & No & No \\
\hline 16 & Acetazolamide & No & No \\
\hline 17 & No & Yes & Yes \\
\hline 18 & Acetazolamide + Slow-K & No & No \\
\hline 19 & $\begin{array}{c}\text { Acetazolamide }+ \\
\text { Topiramate }\end{array}$ & No & Yes \\
\hline 20 & $\begin{array}{c}\text { Acetazolamide }+ \\
\text { Bicarbonate }\end{array}$ & No & Yes \\
\hline 21 & Acetazolamide & No & Yes \\
\hline 22 & Acetazolamide & No & No \\
\hline 23 & Acetazolamide & No & No \\
\hline 24 & Acetazolamide & No & No \\
\hline 25 & $\begin{array}{c}\text { Acetazolamide }+ \\
\text { Topiramate }\end{array}$ & No & No \\
\hline 26 & No & No & No \\
\hline 27 & No & Yes & No \\
\hline 28 & No & Yes & No \\
\hline 29 & Acetazolamide & No & No \\
\hline
\end{tabular}

or absence of papilledema ${ }^{2,17,21}$. Headache relief after lumbar puncture is an alert for the diagnosis of pseudotumor ${ }^{22}$.

The most frequent signs and symptoms in our study were papilledema and headaches, followed by visual loss. Most authors describe headache as the most common symptom ( $61 \%$ to $94 \%$ of cases) ${ }^{18}$. In the study by Tibussek et al., headache was described as chronic, daily, or mimicking acute migrane ${ }^{23}$.

In our study, four patients were diagnosed with pseudotumor secondary to rheumatic diseases; glucocorticoid was used in three of these patients (two in tapering doses); and there was one case related to antiphospholipid syndrome. The study by Sussman et al..$^{24}$ showed that prothrombotic events play an important role in the pathogenesis of pseudotumor. The presence of antiphospholipid antibodies was observed 
in $32 \%$ of the patients ${ }^{24}$. Leker and Steiner's study ${ }^{25}$ described the association of pseudotumor cerebri and the presence of anticardiolipin in six of 14 patients (43\%), suggesting anticardiolipin as a risk factor for a thrombotic cause of pseudotumor cerebri. The presence of these antibodies was assessed only in the patient with antiphospholipid syndrome.

The role of glucocorticoid tapering in triggering pseudotumor has been described. Although the pathogenesis is unknown, patients with onset of headaches after glucocorticoid discontinuation should be evaluated for intracranial hypertension with eye fundoscopy, CSF examination and imaging ${ }^{25}$. However, glucocorticoids are not recommended for the treatment of children with chronic pseudotumor cerebri because of their adverse effects, such as weight gain and rebound of intracranial hypertension during periods of medication tapering ${ }^{25,26}$.

Conditions of hypercoagulability, such as in Behçet's disease and systemic lupus erythematosus, may lead to dural sinus thrombosis and pseudotumor ${ }^{22}$. There are no descriptions in the literature of pseudotumor associated with juvenile dermatomyositis or Henoch-Schönlein purpura in childhood. Therefore, we believe that the true cause of pseudotumor in our patients may have been glucocorticoid tapering, since all patients were receiving this medication in progressively smaller doses. Case reports of patients with Cushing's syndrome have shown that treating hypercortisolism with drugs such as ketoconazole could trigger pseudotumor cerebri ${ }^{27}$.

One of the most frequent causes of pseudotumor in adult patients is obesity ${ }^{9,10}$. However, only three patients in our group were obese.

Similar to the literature, the first-choice medication was acetazolamide (20 patients), followed by topiramate. Both drugs reduce the production of CSF. Acetazolamide decreases the severity of headaches, reduces the risk of papilledema and stabilizes visual function ${ }^{19}$. Current knowledge shows no benefit in multiple relief lumbar punctures due to uncertain results, technical difficulties, need for sedation and rapid reestablishment of previous CSF levels. Some authors recommend the use of glucocorticoids to control CSF production, but their use is restricted to cases of severe headache, severe papilledema and very high intracranial pressure ${ }^{18,25,26}$. A spinal shunt was performed in seven patients due to failure of clinical treatment. Nine patients did not receive medication because their headaches improved after lumbar puncture.

Papilledema in childhood usually disappears after three to six months of treatment, although in some cases it may last longer and lead to atrophy of the optic nerve ${ }^{18}$. Visual loss at onset was reported in $6 \%$ to $20 \%$ of pediatric cases, although loss of the visual field may occur in up to $91 \%$ of these patients ${ }^{18}$. We observed visual loss in two patients. Studies show that children have an increased risk of permanent visual loss due to papilledema ${ }^{12}$.

Among the positive points of our study, we emphasize the description of pseudotumor cerebri associated with rare systemic conditions in pediatric patients, such as in rheumatic diseases. This is a rare and entity that can lead to permanent damage. This study was a pioneer in reporting cases of pseudotumor cerebri associated with juvenile dermatomyositis and Henoch-Schönlein purpura, although the most-likely cause in these patients was glucocorticoid withdrawal.

Since this was a retrospective study, it was impossible to detail the data, such as doses and glucocorticoid reduction. In addition, there was a small number of patients and, in some of them, the determination of antiphospholipid antibodies was not performed.

Although rare, pseudotumor cerebri is a clinically severe syndrome that can cause permanent visual loss in children if not promptly diagnosed. Rheumatic disorders are important causes of this syndrome.

\section{References}

1. Galgano MA, Deshaies EM. An update on the management of pseudotumor cerebri. Clin Neurol Neurosurg. 2013 Mar;115(3):252-9. https://doi.org/10.1016/j.clineuro.2012.11.018

2. Per H, Canpolat M, Gümüș H, Poyrazoğlu HG, Yıkılmaz A, Karaküçük $S$ et al. Clinical spectrum of the pseudotumor cerebri in children: etiological, clinical features, treatment and prognosis. Brain Dev. 2013 Jun;35(6):561-8. https://doi.org/10.1016/j.braindev.2012.08.008

3. Soiberman U, Stolovitch C, Balcer LJ, Regenbogen M, Constantini S, Kesler A. Idiopathic intracranial hypertension in children: visual outcome and risk of recurrence. Childs Nerv Syst. 2011 Nov;27(11):1913-8. https://doi.org/10.1007/s00381-011-1470-5

4. Patiroglu T, Ozcan A, Karakukcu M, Ozdemir MA, Poyrazoglu G, Canpolat M et al. Mycophenolate mofetil-induced pseudotumor cerebri in a boy with autoimmune lymphoproliferative disease. Childs Nerv Syst. 2011 May;27(5):853-5. https://doi.org/10.1007/s00381-011-1402-4
5. Costa KMAH, Almeida JB, Félix RHM, Silva Júnior MF. Pseudotumor cerebral associado ao uso de ciclosporina após transplante renal. J Bras Nefrol. 2010;32(1):138-41. https://doi.org/10.1590/S0101-28002010000100022

6. Spennato P, Ruggiero C, Parlato RS, Buonocore MC, Varone A, Cianciulli E et al. Pseudotumor cerebri. Childs Nerv Syst. 2011 Feb;27(2):215-35. https://doi.org/10.1007/s00381-010-1268-x

7. Digre KB. Idiopathic intracranial hypertension headache. Curr Pain Headache Rep. 2002 Jun;6(3):217-25. https://doi.org/10.1007/s11916-002-0038-1

8. Ko MW, Liu GT. Pediatric idiopathic intracranial hypertension (pseudotumor cerebri). Horm Res Paediatr. 2010;74(6):381-9. https://doi.org/10.1159/000321180

9. Lee AG, Golnik K, Kardon R, Wall M, Eggenberger E, Yedavally S. Sleep apnea and intracranial hypertension in men. Ophthalmology. 2002 Mar;109(3):482-5. https://doi.org/10.1016/S0161-6420(01)00987-3 
10. Pearce J. From pseudotumor cerebri to idiopathic intracranial hypertension. Pract Neurol. 2009;9(6):353-6. https://doi.org/10.1136/jnnp.2009.194837

11. Killer HE, Jaggi GP, Miller NR, Huber AR, Landolt H, Mironov A et al. Cerebrospinal fluid dynamics between the basal cisterns and the subarachnoid space of the optic nerve in patients with papilloedema. Br J Ophthalmol. 2011 Jun;95(6):822-7. https://doi.org/10.1136/bjo.2010.189324

12. Phillips PH. Pediatric pseudotumor cerebri. Int Ophthalmol Clin. 2012;52(3):51-9. https://doi.org/10.1097/II0.0b013e31825a12f6

13. Hacifazlioglu Eldes N, Yilmaz Y. Pseudotumour cerebri in children: etiological, clinical features and treatment modalities. Eur J Paediatr Neurol. 2012 Jul;16(4):349-55. https://doi.org/10.1016/j.ejpn.2011.09.002

14. Distelmaier F, Sengler U, Messing-Juenger M, Assmann B, Mayatepek E, Rosenbaum T. Pseudotumor cerebri as an important differential diagnosis of papilledema in children. Brain Dev. 2006 Apr;28(3):190-5. https://doi.org/10.1016/j.braindev.2005.07.003

15. Dandy WE. Intracranial pressure without brain tumor: diagnosis and treatment. Ann Surg. 1937 Oct;106(4):492-513. https://doi.org/10.1097/00000658-193710000-00002

16. Rangwala LM, Liu GT. Pediatric idiopathic intracranial hypertension. Surv Ophthalmol. 2007 Nov-Dec;52(6):597-617. https://doi.org/10.1016/j.survophthal.2007.08.018

17. Acheson JF. Idiopathic intracranial hypertension and visual function. $\mathrm{Br}$ Med Bull. 2006;79-80(1):233-44. https://doi.org/10.1093/bmb/ldl019

18. Incecik F, Hergüner MO, Altunbașak S. Evaluation of sixteen children with pseudotumor cerebri. Turk J Pediatr. 2011 Jan-Feb;53(1):55-8.

19. Babikian P, Corbett J, Bell W. Idiopathic intracranial hypertension in children: the lowa experience. J Child Neurol. 1994 Apr;9(2):144-9. https://doi.org/10.1177/088307389400900208
20. Standridge SM. Idiopathic intracranial hypertension in children: a review and algorithm. Pediatr Neurol. 2010 Dec;43(6):377-90. https://doi.org/10.1016/j.pediatrneurol.2010.08.001

21. Friedman D, Liu G, Digre K. Revised diagnostic criteria for the pseudotumor cerebri syndrome in adults and children. 2013 Sep;81(13):1159-65. https://doi.org/10.1212/WNL.0b013e3182a55f17

22. Değerliyurt A, Teber S, Karakaya G, Güven A, Șeker ED, Arhan EP et al. Pseudotumor cerebri/idiopathic intracranial hypertension in children: an experience of a tertiary care hospital. Brain Dev. 2014 Sep;36(8):690-9. https://doi.org/10.1016/j.braindev.2013.09.007

23. Tibussek D, Schneider DT, Vandemeulebroecke N, Turowski B, Messing-Juenger M, Willems $\mathrm{PH}$ et al. Clinical spectrum of the pseudotumor cerebri complex in children. Childs Nerv Syst. 2010 Mar;26(3):313-21. https://doi.org/10.1007/s00381-009-1018-0

24. Sussman J, Leach M, Greaves M, Malia R, Davies-Jones GA. Potentially prothrombotic abnormalities of coagulation in benign intracranial hypertension.J Neurol Neurosurg Psychiatry. 1997 Mar;62(3):229-33. https://doi.org/10.1136/jnnp.62.3.229

25. Leker RR, Steiner I. Anticardiolipin antibodies are frequently present in patients with idiopathic intracranial hypertension. Arch Neurol. 1998 Jun;55(6):817-20. https://doi.org/10.1001/archneur.55.6.817

26. Jindal M, Hiam L, Raman A, Rejali D. Idiopathic intracranial hypertension in otolaryngology. Eur Arch Otorhinolaryngol. 2009 Jun;266(6):803-6. https://doi.org/10.1007/s00405-009-0973-0

27. Costenaro F, Rodrigues TC, Ferreira NP, Costa TG, Schuch T, Boschi V, Czepielewski MA. Pseudotumor cerebral durante o tratamento de doença de Cushing com cetoconazol. Arq Bras Endocrinol Metabol. 2011 June;55(4):284-7. https://doi.org/10.1590/S0004-27302011000400008 